Sri Lanka J. Aquat. Sci. 13 (2008): 1-21

\title{
Fishery and feeding habits of yellowfin tuna (Thunnus albacares) targeted by coastal tuna longlining in the north western and north eastern coasts of Sri Lanka
}

\author{
D.C.T. DISSANAYAKE*, E.K.V. SAMARAWEERA AND C. \\ AMARASIRI
}

Marine Biological Resources Division, National Aquatic Resources Research and Development Agency, Crow Island, Colombo 15, Sri Lanka.

*Corresponding author (E-mail: chamari@nara.ac.lk)

\begin{abstract}
Present study analyzed the catch, effort and size distribution of yellowfin tuna (Thunnus albacares) caught by coastal tuna longlining in north western and north eastern coastal waters of Sri Lanka from January 2005 to December 2006. Further, the contents of 83 non-empty stomachs were analyzed and the indices such as frequency of occurrence ( $\%$ ), percentage of number of each food (\%), percentage of wet weight of each food item $(\% W)$ and percentage index of relative importance of each food item $(\% I R I)$ were calculated for the specimens caught from north western coastal waters from September 2006 to April 2007. W eekly fishery data were collected at major landing sites in north western and north eastern coastal areas. The fishing activities were carried out using Fiberglass Reinforced Boats (FRP) with outboard engine which basically operated in coastal waters during one day trip duration. The fishery was highly seasonal and it related to the monsoon pattern. Fishing started in October and continued until April of the following year in north western coast and from May to September in north eastern area. The estimated figure for total production in north western area (1052 t in 2005 and $3313 \mathrm{t}$ in 2006) was higher than that in the north eastern area (578 $\mathrm{t}$ in 2005 and $741 \mathrm{t}$ in 2006) and it was significant in 2006 $(\mathrm{P}<0.05)$. Total fishing effort in north western coast was much higher than in the north eastern coast in both years but the difference was not significant. The $\log$ transformed catch per unit effort $\ln (\mathrm{CPUE}+1)$ values were not significantly different in the two areas. Distribution classes of the length range of yellowfin tuna was within $30-150 \mathrm{~cm}$ in the catches and dominant length classes laid within the range of 95 to $120 \mathrm{~cm}$ and forward shifting of dominant peaks were evident within the fishing season. In the stomachs of yellowfin tuna sampled, on average 33 prey items were found per stomach
\end{abstract}


and dominant prey items were crustaceans, especially the swimming crab, Charybdis smithii followed by fishes belonging to family Sphyraenidae and Engraulididae. Loligo bartrami belonging to familyLoliginidae, formed the main cephalopod prey. \% IRI of crustaceans was higher than that of fish and cephalopods and this further revealed that the pelagic crabC. smithii is the most important prey item in the diet of yellowfin tuna.

\section{Introduction}

Tunas (Family: Scombridae) are reported to be found in temperate and tropical oceans around the world and account for a major proportion of the world's fishery products (Collette and Nauen 1983). Sri Lanka is one of the oldest and most important tuna producing island nations in the Indian Ocean. Exploration and exploitation of the fishery resources in the Indian Ocean area over the past three decades have shown that the tuna resources in Sri Lanka consist of Yellowfin tuna (Thunnus albacares), Big eye tuna (Thunnus obsesus), Skipjack tuna (Katsuwonus pelamis), Kawakawa (Enthynnus affinis), Frigate tuna (Auxis thazard) and Bullet tuna (Auxis rochei) (Joseph et al. 1985; Samaraweera and Amarasiri 2004). The latter four species are generally considered to be insular with localized migratory habits (Sivasubramaniam 1971). First two species are known to be widely distributed not only in the local areas, but also in other parts of the Indian ocean and the distribution of these oceanic species are not clearly understood (Sivasubramaniam 1985).

Gillnets alone or in combination with other gear such as longline, purse seine and handline are the main fishing gear used in tuna fisheries in Sri Lanka. Gillnets are used in combination with purse seine and longline in southern, southeastern and southwestern coastal waters while in the western, north-western and eastern marine areas they are used in combination with longlines. Use of longlines for tuna fishery came into existence in the late 1950 's but it did not sustain due to declining of hook rates and unavailability of suitable baits. Longlining for tuna has been reintroduced to offshore and deep sea fisheries in late 1980's and few multiday boats used to practice that activity. Several subsidies were given to multiday boats to promote longlining in the offshore waters during that period. Gradually this has become successful for yellowfin tuna and at present longlines account for around $20 \%$ of fishing gear in the multiday offshore fisheries. Export of chilled large yellowfin tuna has become a lucrative venture in recent years and the quality of fish is an extremely important factor for maintaining at the export market (Dissanayake 2006).

With the increasing demand for yellowfin tuna in local as well as export market, smaller day boats also started using longlining for yellowfin tuna which inhabit in coastal waters. The fishing activity is restricted only to coastal waters during the non monsoonal period. At present there is a well established longline fishery for yellowfin tuna in the north western and north 
eastern coastal waters of Sri Lanka where smaller day-boats $(5.5-7.2 \mathrm{~m}$ with 9-15 HP outboard engines) are used as the fishing vessel. It is assumed that surface inhabiting young and immature yellowfin tuna enters into the coastal waters and these young fish are believed to support for the coastal longline fisheries in these areas (Sivasubramanium 1970; Maldeniya and Joseph 1988). Though considerable amount of yellowfin tuna landings have been reported from smaller day-boats during fishing season, very few studies have been carried out on this fishery compared to the offshore tuna longline fisheries. Hence, the present study attempts to analyze the catch, effort, length frequency distribution and other fishery related information such as fishing season, fishing time, bait, fishing depth and fishing grounds of yellowfin tuna which are targeted by longlines in day- boats off north western and north eastern coastal waters of Sri Lanka. According to Blackburn and Laurs (1972), availability of yellowfin tuna to the fishing gear depends on the forage type, migration pattern and environmental constrains. It is very important to know about the preferred forage types of yellowfin tuna because it is useful to identify suitable bait for longlining. In this study, attempts were made to analyses the gut contents of yellowfin tuna which were caught from northwestern coastal waters of Sri Lanka from September 2006 to April 2007.

\section{Materials and Methods}

\section{Collection of catch and effort data}

Catch, effort and biological data of the coastal tuna longline fishery were collected at the major landing sites in northwestern (Thalawila and Kandakuliya) and northeastern (Trincomalee) coastal waters of Sri Lanka from January 2005 to December 2006 (Figure 1). The catch data were collected by making regular weekly field visits to the landing sites. The fishing craft used in the fishery was Fibre-Reinforced Plastic (FRP) boats with $9 \mathrm{Hp}$ or $15 \mathrm{Hp}$ outboard motors operated by two fishers. On each day, $40-50 \%$ of the total boats (small FRP day boats) operated were sampled randomly. Sampling was done as soon as the catch was landed. At the landing sites, the fork length of each individual was measured to the nearest $0.1 \mathrm{~cm}$ using a measuring tape. Number of hooks, type of bait, time of fishing and information about the fishing grounds were obtained by interviewing the fishers. The total number of boats operated in each day was also recorded to estimate the total daily catch. 

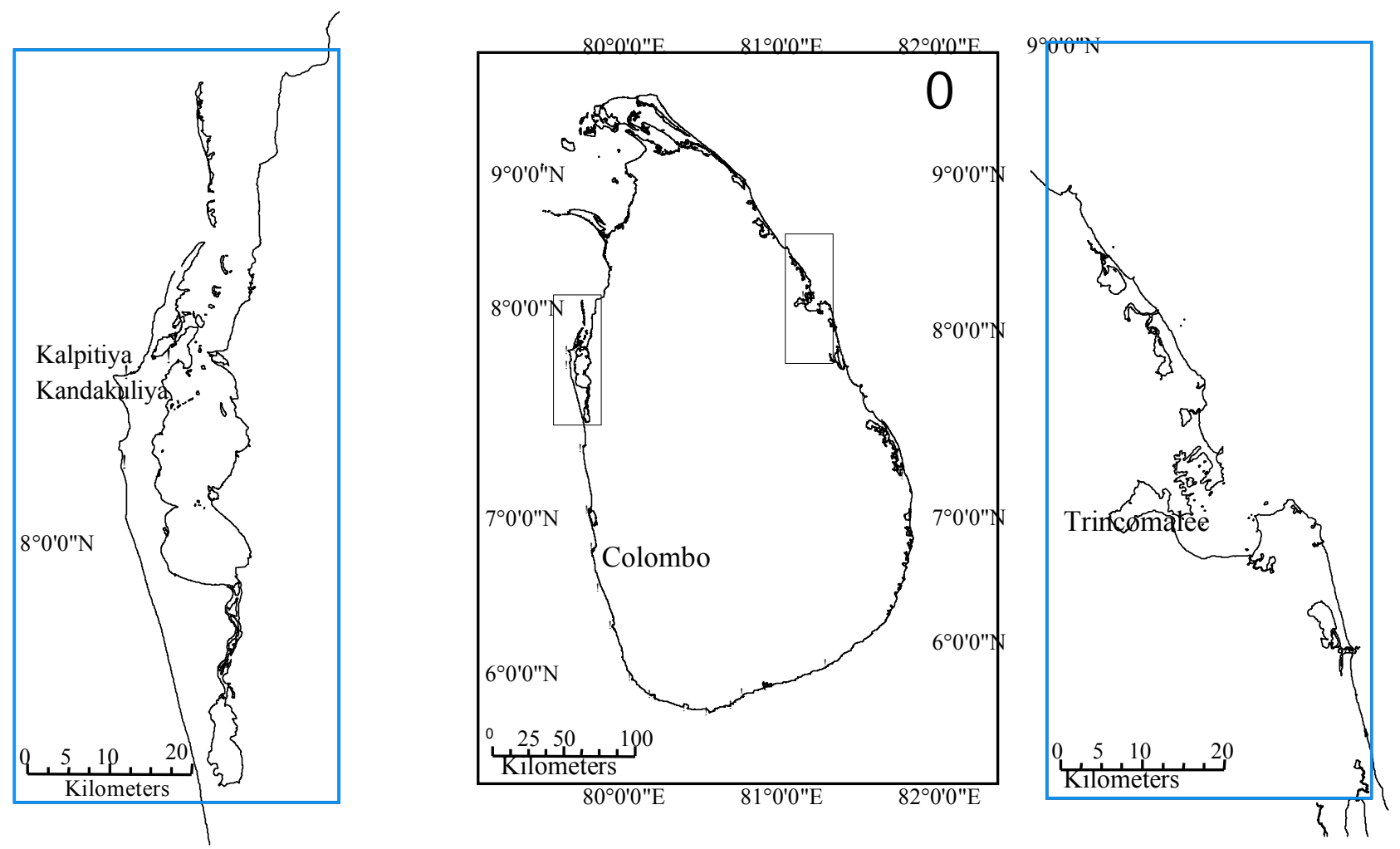

Figure 1. Major landing sites in northwestern and northeastern coasts 


\section{Collection of stomach samples}

Gut samples of yellowfin tuna were collected from the JC foods Private Limited during processing. Before collecting the gut samples, fork length of each individual was measured to the nearest $0.1 \mathrm{~cm}$ using a measuring tape. The total weight of each individual was also measured using an electric balance. Gut samples were transported to the laboratory of National Aquatic Resources Research and Development Agency (NARA) and kept frozen at $-20^{\circ} \mathrm{C}$.

\section{Data analysis}

In the present analysis, two measures of fishing effort i.e. boat-days and 1000 hook-days were used. Total catch and effort for each month and the monthly variation of the catch were estimated from the data collected on each sampling day. Catch per unit effort (CPUE) was estimated for both measures of fishing effort as $\mathrm{kg}$ per boat-day and $\mathrm{kg}$ per1000 hook-days. Fishing effort, In (CPUE +1$)$, total catch of two different areas were statistically compared using Students' t-test. The MINITAB (version 14) software package was used for statistical analysis. Length frequency distributions of two different areas were computed and compared using $\mathrm{R}$ package ( $\mathrm{R}$ work, V ersion 2.5, http://www.r-project.org).

\section{Stomach content analysis}

Each gut sample was thawed and drained before analysis. The Stomach length and total gut length were measured to the nearest $0.1 \mathrm{~cm}$ using a measuring tape. The total weight of stomach contents was determined to the nearest $0.01 \mathrm{~g}$ using an electric balance. Accumulated items, i.e. indigestible hard parts of prey items that were accumulated over time (e.g. cephalopod beaks without flesh attached and eroded fish otoliths), were sorted and excluded from the analysis because they overemphasize the importance of some prey in fish diets. The contents were divided into broad prey classes (crustaceans, fishes, squids, others), which were weighed to estimate their proportions by wet mass in the diet. The different items constituting a single class were sorted and counted. Identifiable fresh remains were used to determine the number of each prey item. The each prey item was identified to the lowest possible taxon using keys (Fishcer and Bianci 1984). Prey items were measured using standard length (SL in cm) for fishes, the mantle length (in $\mathrm{cm}$ ) for cephalopods, and carapace width (between two lateral spines, in $\mathrm{cm}$ ) for pelagic crabs.

The quantitative importance of each prey group was determined by using the Index of Relative Importance (IRI) which was defined as follows (Pinkas et al. 1971).

$$
\text { IRI } \quad=\% \mathrm{~F}(\% \mathrm{~N}+\% \mathrm{~V})
$$

Where, $\% \mathrm{~F}-$ Frequency of occurrence of the food item, $\% \mathrm{~N}-$ Numerical percentage of a food item in the stomachs, $\% \mathrm{~V}$ - Percentage by volume of the food item in the stomach 
In this analysis percentage weight $(\% \mathrm{~W})$ was used instead of volume $(\% \mathrm{~V})$ and this modified index can be expressed as

$$
\% \text { IRI }=\left(\text { IRI } / \sum \text { IRI }\right) \times 100
$$

\section{Results}

\section{Fishing season}

Yellowfin tuna fishery is a seasonal fishing activity and is greatly influenced by the monsoon winds. The monsoon brings about much wave action and currents in the sea which make difficult to use the gear. As such there are essentially two major coastal tuna longline fisheries one off the west coast during the northeast monsoon and one off the east coast during the southwest monsoon. Along the north western coast, fishing starts in October and continues until the end of April of the following year and in the north eastern coast it starts in May and continues until September. Slight differences in the fishing season occur in the same year in accordance with the monsoon pattern.

\section{Fishing gear and operations}

The structure of the gear was similar in both the fishing areas. Generally the gear was rigged with monofilament lines to fish at depths of 50-80 m. Locally-made cube shaped rigifoam blocks $(300 \times 300 \times 150 \mathrm{~mm})$ or G-7 type rigifoam buoys with a flagged pole were attached to each end of the line. A 1-2 kg cement block was attached to the bottom of the flagged pole to keep it upright.

The fishing craft used in the fishery was Fiberglass Reinforced Plastic (FRP) boats with outboard motors operated by two fishermen. The engine power is either $9 \mathrm{Hp}$ or $15 \mathrm{Hp}$. The average number of hooks per boat varied from 80 to 100 in the northeastern coast and from 160 to 210 hooks in the north western coast.

The fishing crafts left around 5.00 a.m. - 6.00 a.m. and returned around 11.00 a.m. -1.00 p.m. in the north eastern areas. The effective fishing time ranged from 3-4 hours per day. Night fishing was carried out in the north western zone and fishing was from around $4.30 \mathrm{pm}-5.30 \mathrm{pm}$ to around $8.00 \mathrm{pm}-10.00 \mathrm{pm}$. The effective fishing time was much similar to north eastern area ( $3-4$ hours). The information about the fishing ground such as average fishing depths and average distance to fishing ground from the coast is summarized in Table 1.

Different types of baits were used for longlines and widely used bait types are summarized in Table 2 according to the area. Exocoetids and Clupeids were commonly used baits in both areas while carangids and loliginids were restricted to the north eastern area. 
Table 1. Information about the fishing grounds

\begin{tabular}{lcc}
\hline Fishing area & $\begin{array}{c}\text { Average } \\
\text { depth }\end{array}$ & $\begin{array}{c}\text { Average distance to fishing ground } \\
\text { from the coast }\end{array}$ \\
\hline North Eastern & $50-70 \mathrm{~m}$ & $20-25 \mathrm{~km}(10-12$ Nautical miles $)$ \\
North W estern & $50-70 \mathrm{~m}$ & $15-20 \mathrm{~km}(8-10$ Nautical miles $)$ \\
\hline
\end{tabular}

Table 2. Widely used bait types for tuna longline fishery in two different areas

\begin{tabular}{|c|c|c|c|}
\hline Family & Scientific name & English name & Area \\
\hline \multirow[t]{2}{*}{ Carangidae } & Decapterus russelli & Indian Scad & $\begin{array}{l}\text { Northeastern } \\
\text { coast }\end{array}$ \\
\hline & $\begin{array}{l}\text { Decapterus } \\
\text { macarellus }\end{array}$ & Mackerel scad & $\begin{array}{l}\text { Northeastern } \\
\text { coast }\end{array}$ \\
\hline Exocoetidae & $\begin{array}{l}\text { Cheilopogon spp } \\
\text { Cypselurus spp } \\
\text { Hirundichthys spp. }\end{array}$ & $\begin{array}{l}\text { Flyingfish } \\
\text { species }\end{array}$ & $\begin{array}{l}\text { Northeastern \& } \\
\text { Northwestern }\end{array}$ \\
\hline Clupeidae & Amblygaster sirm & $\begin{array}{l}\text { Spotted } \\
\text { Sardinella }\end{array}$ & $\begin{array}{l}\text { Northeastern \& } \\
\text { Northwestern }\end{array}$ \\
\hline Loliginidae & Loligo spp. & Squids & Northeastern area \\
\hline
\end{tabular}

\section{Catch composition}

Yellowfin tuna (Thunnus albacares) was dominated in the catches (97\% of the total catch) and some carangid species, sword fish (Xiphias gladius) and small skipjack tuna (Katsuwonus pelamis) were reported very rarely during the study period. The latter three species represented $1 \%, 0.8 \%$ and $1.2 \%$ of the total catch respectively.

\section{$\mathrm{V}$ ariation in total fishing effort and total production}

Figures 2 and 3 show the variation of total fishing effort (average number of boats operated per day $\mathrm{x}$ number of fishing days) and total yellowfin tuna production (in tonnes) in the two fishing areas studied. Total fishing effort in north western coast was much higher than the north eastern coast in both the years but the difference was not significant $(p>0.05)$ possibly due to high variability. When the monthly fishing effort was 
compared within the area for 2005 and 2006, the difference was not statistically significant either in northwestern coast $(\mathrm{t}=0.52, \mathrm{df}=22, \mathrm{p}=$ $0.61)$ or north eastern coast $(t=0.30, d f=22, p=0.76)$.

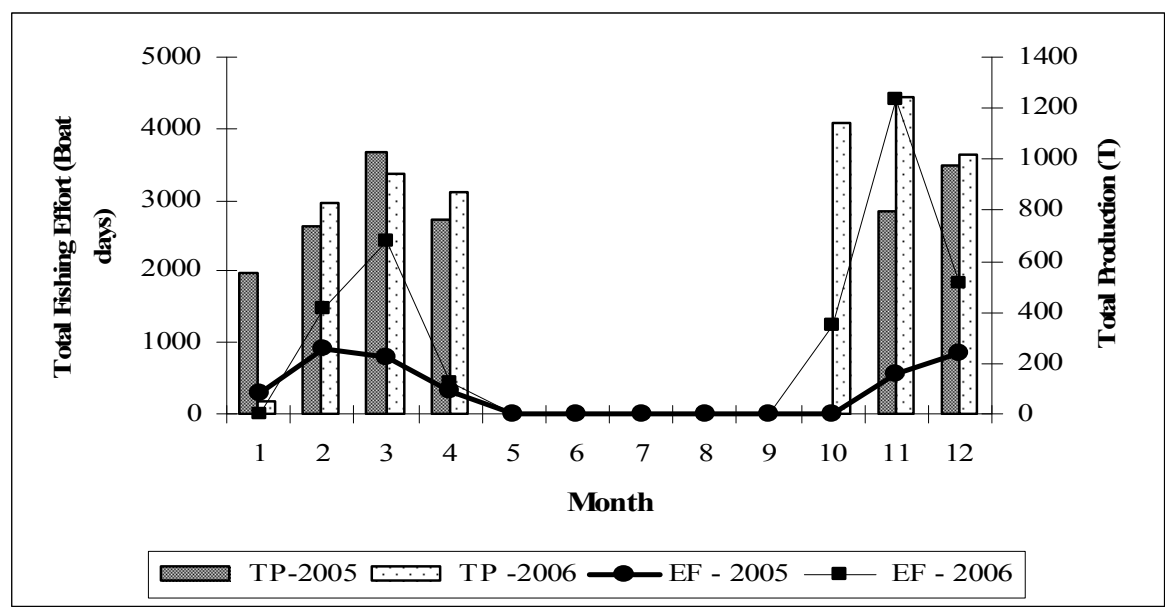

Figure 2. Monthly variation of total fishing effort (EF) and total yellowfin tuna production (TP) in north western coast in 2005 and 2006

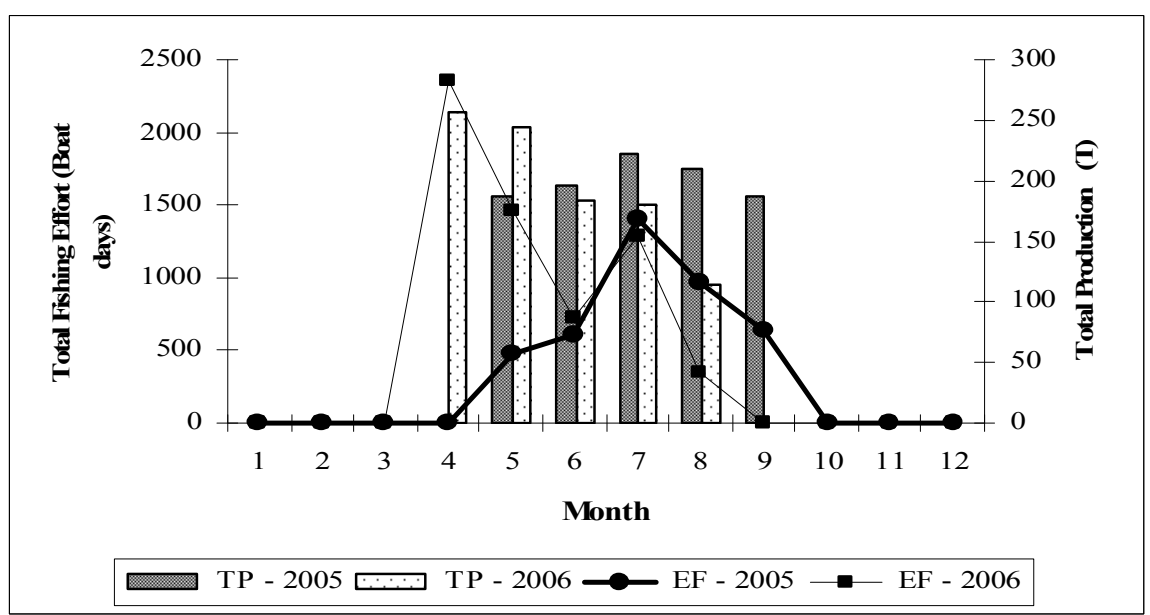

Figure 3. Monthly variation of total fishing effort (EF) and total yellowfin tuna production (TP) in north eastern coast in 2005 and 2006

Total yellowfin tuna production ranged from 1052 tonnes in 2005 to 3313 tonnes in 2006 in the north western area and 578 tonnes in 2005 to 741 tonnes in 2006 in the north eastern area. The estimated total production was higher in north western area compared to the north eastern coast and it was 
significant in $2006(\mathrm{p}>0.05)$. Total yellowfin tuna production was not significantly different between 2005 and 2006 in both fishing areas (p > $0.05)$. In north western coast, the reported highest production was in March for 2005 and in November for 2006. In the north eastern coast peak production was in July 2005 and April 2006.

\section{Catch Per Unit Effort (CPUE)}

Monthly variation of CPUE ( $\mathrm{kg} 1000$ hooks $\left.{ }^{-1}\right)$ was estimated and the variations in $\ln (\mathrm{CPUE}+1)$ are summarized in Figures 4 and 5. The average CPUE was not significantly different from each other in the north western and north eastern zones $(p>0.05)$. Further there was no significant difference in average CPUE within the area for two different years $(p>0.05)$.

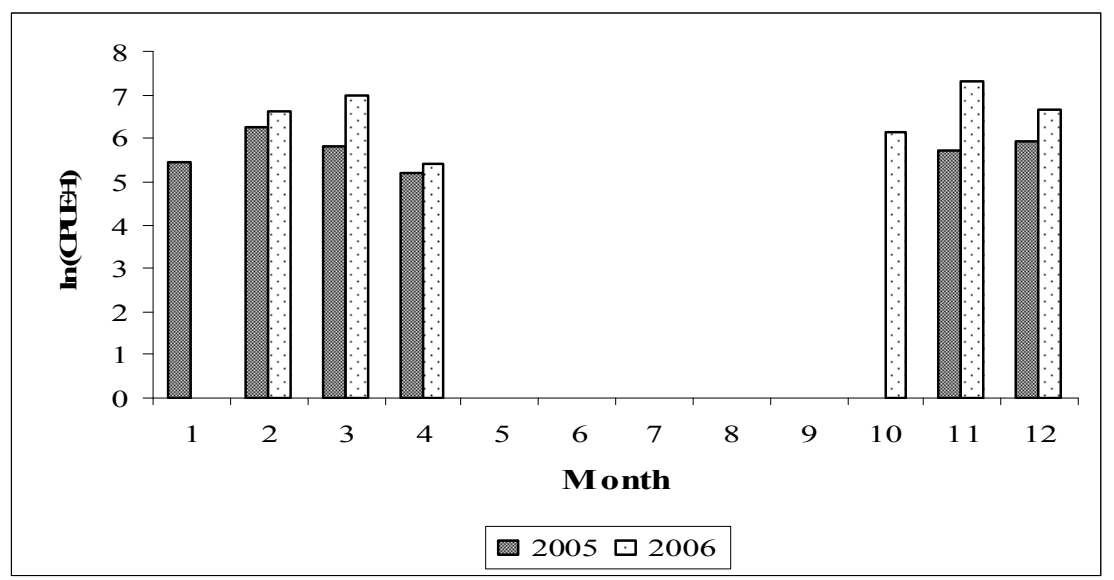

Figure 4. Monthly variation of $\ln (\mathrm{CPUE}+1)$ in north western coast in 2005 and 2006

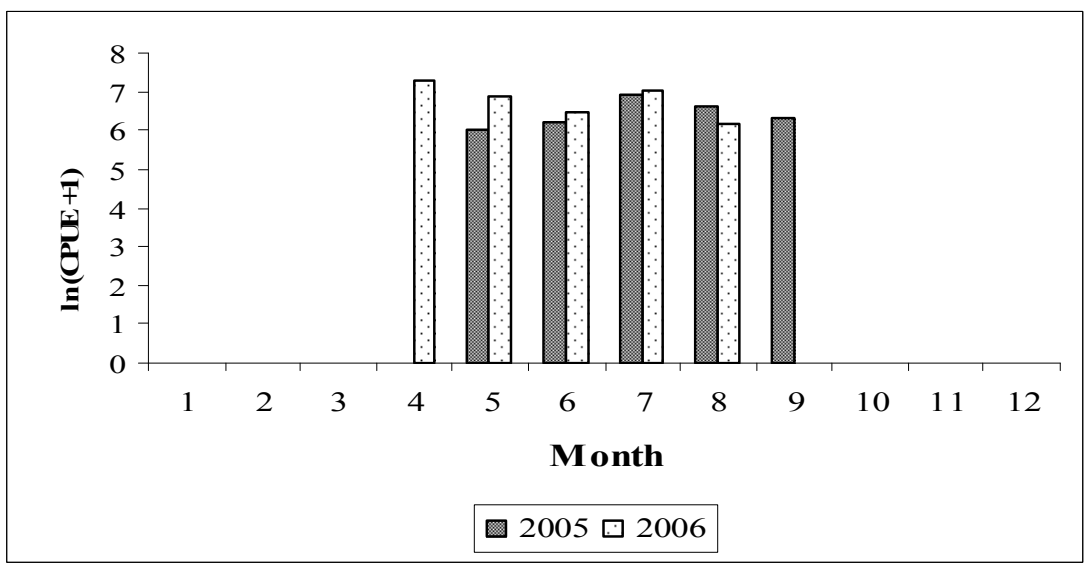

Figure 5. Monthly variation of $\ln (\mathrm{CPUE}+1)$ in north eastern coast in 2005 and 2006 
Table 3 summarizes the estimated values of CPUE expressed as catch per boat-day. Estimated CPUE in the north western area ranged from 33 to $97 \mathrm{~kg}$ in 2005 and 41 to $277 \mathrm{~kg}$ in 2006. It ranged from 37 to $90 \mathrm{~kg}$ and from 42 to $132 \mathrm{~kg}$ in north eastern coast for the 2005 and 2006 respectively.

Table 3. Monthly variation of Catch boat $\operatorname{day}^{-1}(\mathrm{~kg})$ in two different areas

\begin{tabular}{rcccc}
\hline \multirow{2}{*}{ Month } & \multicolumn{2}{c}{ North Western Zone } & \multicolumn{2}{c}{ North Eastern Zone } \\
\cline { 2 - 5 } & $\mathbf{2 0 0 5}$ & $\mathbf{2 0 0 6}$ & $\mathbf{2 0 0 5}$ & $\mathbf{2 0 0 6}$ \\
\hline January & 43.31 & 0.00 & 0.00 & 0.00 \\
February & 97.53 & 139.42 & 0.00 & 0.00 \\
March & 60.44 & 201.39 & 0.00 & 0.00 \\
April & 33.21 & 41.03 & 0.00 & 132.31 \\
May & 0.00 & 0.00 & 37.13 & 86.08 \\
June & 0.00 & 0.00 & 44.74 & 57.05 \\
July & 0.00 & 0.00 & 90.80 & 102.76 \\
August & 0.00 & 0.00 & 66.58 & 43.05 \\
September & 0.00 & 0.00 & 48.62 & 0.00 \\
October & 0.00 & 84.58 & 0.00 & 0.00 \\
November & 56.79 & 277.32 & 0.00 & 0.00 \\
December & 68.03 & 141.90 & 78.63 & 0.00 \\
\hline
\end{tabular}

\section{Length frequency distribution}

Length frequency distributions of yellowfin tuna caught in the North western and the north eastern coastal waters of Sri Lanka are shown in Figures 6 and 7 respectively. The length distribution of yellowfin tuna ranged from $30.0 \mathrm{~cm}$ to $150.0 \mathrm{~cm}$ in both the areas. The smallest length classes were dominant in latter part of the year (November and December 2005 and October to December 2006) and larger length classes were dominant during early months of the year (January to April 2005 and February to April 2006) in the north western coast. The length classes of $102.5 \mathrm{~cm}, 107.5 \mathrm{~cm}, 112.5$ $\mathrm{cm}$ and $117.5 \mathrm{~cm}$ showed peaks from January to April and those of $92.5 \mathrm{~cm}$ and $97.5 \mathrm{~cm}$ had peaks from October to December.

The same pattern could be observed in the north eastern coast during April to September in the two years. Three peaks were observed in the lengths of 97.5, 102.5 and $107.5 \mathrm{~cm}$ from May to September 2005 and another peak was dominant in December 2005 in the length of $87.5 \mathrm{~cm}$. The highest frequency was observed $97.5 \mathrm{~cm}$ length when the fishing was started in May 2005 and it has shifted to $102.5 \mathrm{~cm}$ and $107.5 \mathrm{~cm}$ in June 2005 and August 2005 respectively. Three peaks were evident in 2006 in the lengths of $107.5 \mathrm{~cm}, 112.5 \mathrm{~cm}$ and $117.5 \mathrm{~cm}$. The peak was in $107.5 \mathrm{~cm}$ length when the fishery was started in April 2006 and it has been shifted to $112.5 \mathrm{~cm}$ in June 2006 and $117.5 \mathrm{~cm}$ in July 2006. 

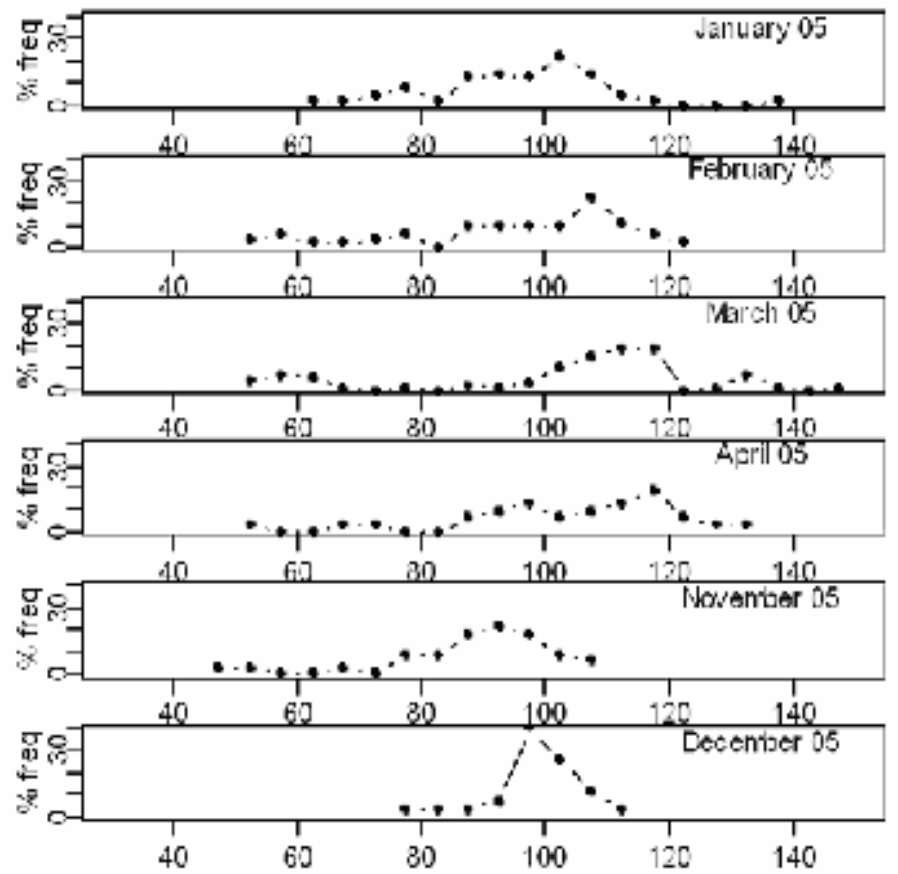

Length (cm)
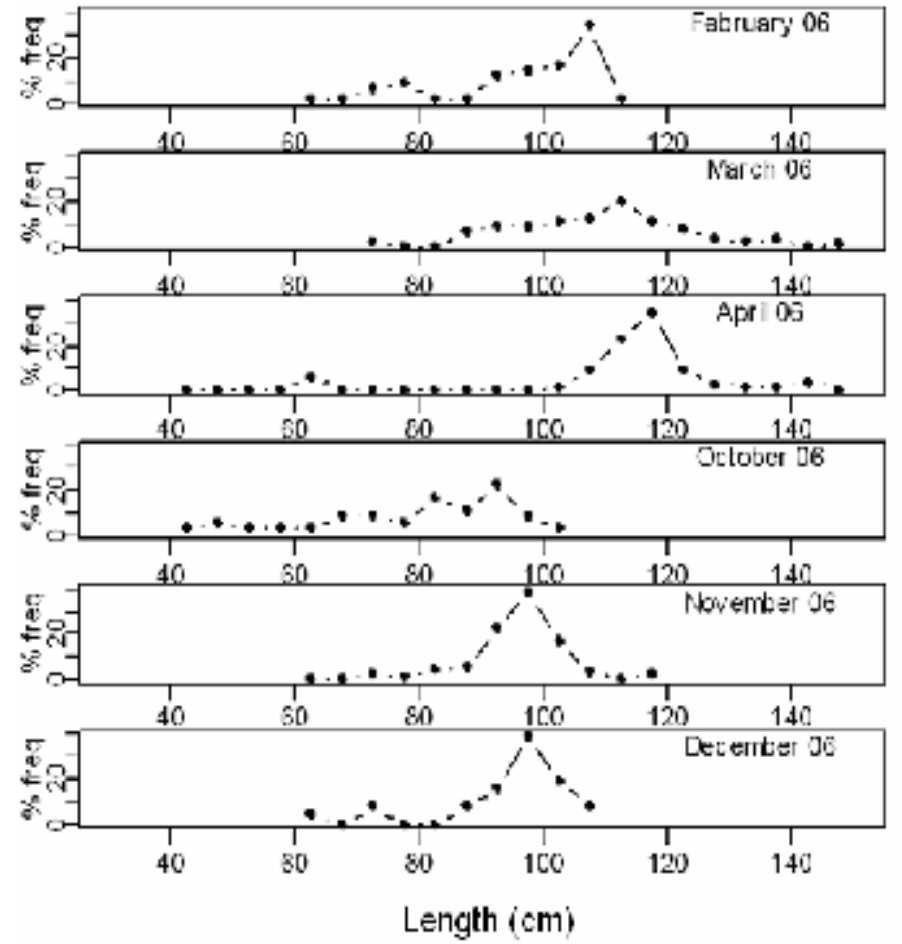

Figure 6. Length frequency distributions of yellowfin tuna in north western coast 

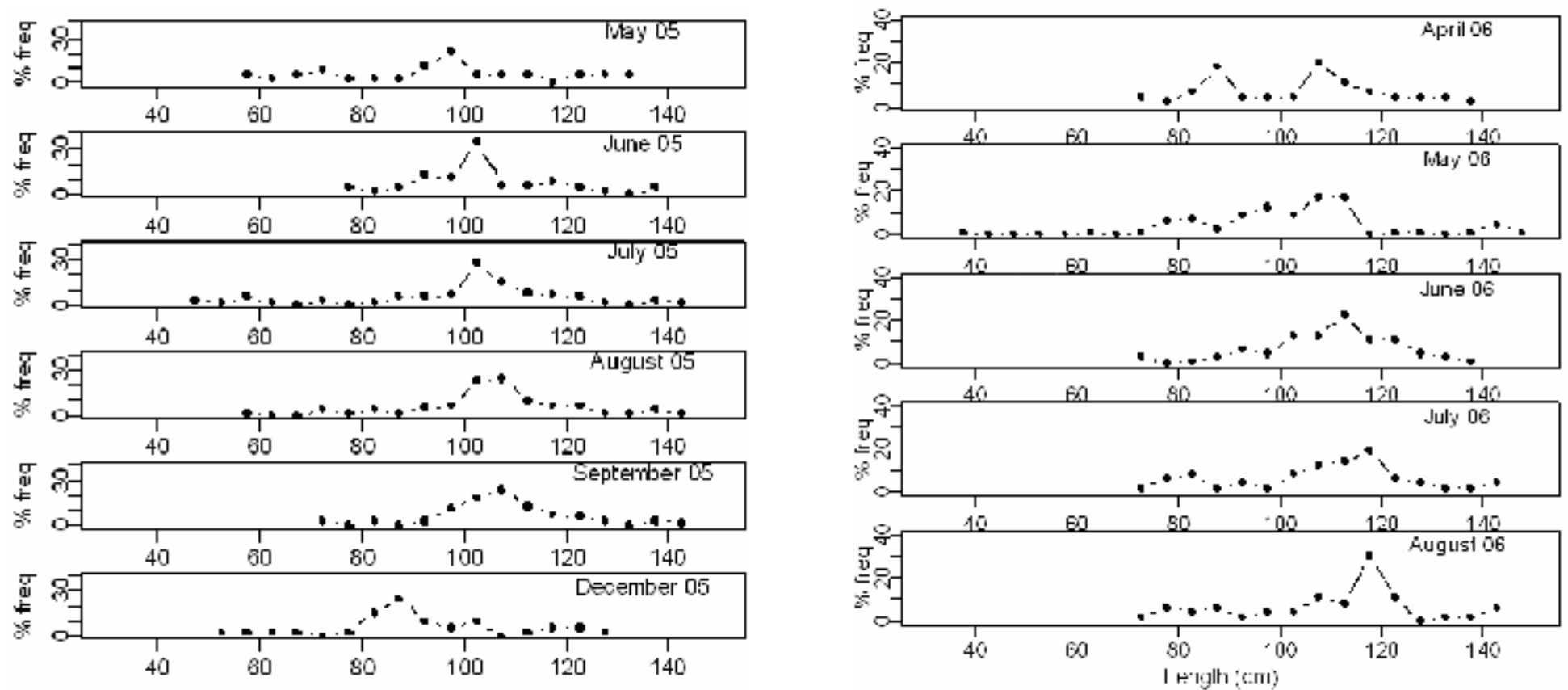

Figure 7. Length frequency distributions of yellowfin tuna in north eastern coast 


\section{Food and feeding habits -morphometric relationships}

The length-weight relationship of yellowfin tuna used for gut content analysis is shown in Figure 8 from which an isometric growth is evident. The important morphometric parameters related to feeding habits of yellowfin tuna are given in Table 4. The estimated average gut weight was $551.50 \mathrm{~g}$ (ranged from 267.90 - $1068.64 \mathrm{~g}$ ) of which $82.40 \%$ represents stomach while the rest $(17.60 \%)$ represents the digested food items in the intestine. The average ratio of total length to gut length was 0.82 and in an average gut length is greater than 2.5 folds compared with the stomach length. The average ratio of total body weight to gut weight was accounted for 0.02 . On the other hand around $20 \%$ of body weight was represented by the gut.

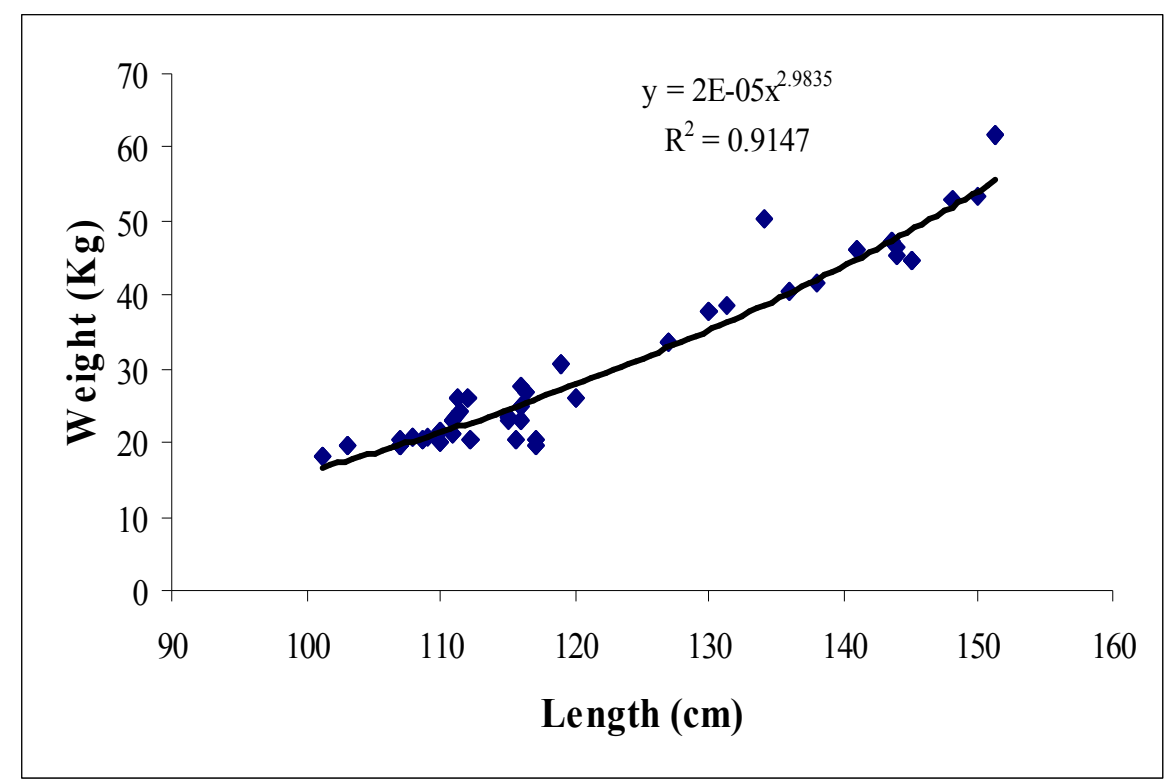

Figure 8. Length weight relationship of yellowfin tuna.

\section{Diet analysis}

A total of 83 stomachs were analyzed during the study period, including 12 empty stomachs and 71 that contained food remains. Of these 71 stomachs, 28 were partially filled and 43 were full with prey items. The proportion of empty stomachs was $14.8 \%$ while the partially filled and full stomachs were $33.3 \%$ and $51.9 \%$ respectively. The average wet weight of the gut contents of 71 stomach samples of yellowfin tuna was $294.22 \mathrm{~g}$ (ranged from 139.08 to $661.16 \mathrm{~g}$ ).

\section{Taxonomic analysis of the prey}

Twenty five species belong to twelve families were dominated in the stomachs of the 83 yellowfin tunas sampled. On average, 33 preys were 
found per stomach. The portunid, Charybdis smithii dominated the diet of yellowfin tuna followed by fish belong to family Sphyraenidae and Engraulididae. Loligo bartrami belonging to familyLoliginidae, formed the main cephalopod prey. The identified prey items / group together with the average length and weight of each prey group are summarized in Table 5.

Table 4. The average values and the value range of some important morphometric parameters related to feeding habits of yellowfin tuna

\begin{tabular}{llll}
\hline No & Parameter & $\begin{array}{l}\text { Average } \\
\text { value }\end{array}$ & Range \\
\hline 1 & Length of fish $(\mathrm{cm})$ & 120.7 & $101.2-148.0$ \\
2 & W eight of fish $(\mathrm{kg})$ & 29.44 & $40.48-53.02$ \\
3 & Total gut length $(\mathrm{cm})$ & 98.9 & $67.20-126.2$ \\
4 & Total gut weight $(\mathrm{cm})$ & 551.50 & $267.90-1068.64$ \\
5 & Stomach length $(\mathrm{cm})$ & 27.5 & $19.30-37.10$ \\
6 & Stomach weight $(\mathrm{kg})$ & 454.43 & $98.97-931.03$ \\
7 & Intestinal length $(\mathrm{cm})$ & 71.48 & $42.00-98.00$ \\
8 & Intestinal weight $(\mathrm{kg})$ & 97.02 & $49.92-157.20$ \\
9 & $\begin{array}{l}\text { Ratio of total length to gut } \\
\text { length } 0.82\end{array}$ & $0.60-0.94$ \\
10 & $\begin{array}{l}\text { Ratio of total weight to gut } \\
\text { weight }\end{array}$ & 0.02 & $0.01-0.04$ \\
11 & $\begin{array}{l}\text { Ratio of gut weight to stomach } \\
\text { weight }\end{array}$ & & 0.83 \\
\hline
\end{tabular}

\section{Discussion}

The ban on the use of high-powered outboard motors in the boats in the north western and north eastern areas due to prevailing security situation may have caused to restrict the exploitation level in the coastal longlining fishery for yellowfin tuna in most areas of Sri Lanka. As a result, the coastal longline fishery for tuna using small boats has become popular among fishermen since mid 1980's (Maldeniya 1995).

Total production of yellowfin tuna was very low during the period of 1993 to 1995 [400 t in 1993, $73 \mathrm{t}$ in 1994 and $127 \mathrm{t}$ in 1995 (Maldeniya 1995)] compared to the estimated values in the present study. It has highlighted the continuous increase of yellowfin tuna production in Indian Ocean during last few years (Nishida and Shono 2006). The reasons for this event was not clear and some oceanographic features were thought to have enhanced the aggregation of tuna which also influenced higher concentration of food items of yellowfin tuna and large recruitments to the population during the period of $1998-1999$ (IOTC 2004). 
Table 5. Prey species or categories, average length and weight ( \pm SD) of prey items recovered from stomach contents yellowfin tuna

\begin{tabular}{lccc}
\hline Group & Species & Average & Average \\
& & $\begin{array}{c}\text { Aventh of } \\
\text { lengteight of prey } \\
\text { prey item } \\
(\mathrm{cm}) \pm \mathrm{SD}\end{array}$ & $\begin{array}{c}\text { item }(\mathrm{g}) \pm \mathrm{SD} \\
\end{array}$ \\
\hline
\end{tabular}

\section{FISH}

Bramidae

Caesionidae

Carangidae

Clupeidae

Ambassidae

Sphyraenidae

Trichiuridae

\section{CEPHALOPODS}

Loliginidae
Brama brama

Dipterygonotus spp

Decapterus russelli

Decapterus spp.

Amblygaster sirm

Amblygaster

clupeoides

Sardinella spp.

Hilsa kelee

Engraulididae Stolephorus spp

Thryssa spp

Cheilopogon

spilopterus

Cheilopogon spp.

Hirundichthys spp.

Cypselurus spp.

Ambassis spp.

Sphyraena spp

Lepturacanthus spp

Trichiurus spp

Loligo spp (small)

Loligo bartrami

CRUST ACEANS

Portunidae

Peneidae
Charybdis smithii

(small)

Charybdis smithii

(Medium)

Penaeus spp.

\section{3}

4

$21.5 \pm 6.8$

$130.45 \pm 12.32$

6

55

69

$5.93 \pm 4.27$

$14.7 \pm 3.3 \quad 35.47 \pm 8.95$

$16.6 \pm 2.1 \quad 40.35 \pm 12.44$

$111 \quad 5.4 \pm 1.3 \quad 5.45 \pm 2.35$

$52 \quad 18.6 \pm 2.9 \quad 22.50 \pm 7.85$

12

$3.7 \pm 1.4$

$3.00 \pm 1.25$

151

$22.3 \pm 5.8$

$22.30 \pm 8.55$

$83 \quad 14.8 \pm 3.6 \quad 14.87 \pm 12.55$

183

129

54

$$
3.0 \pm 0.7 \quad 40.54 \pm 5.80
$$$$
11.3 \pm 1.3 \quad 4.00 \pm 1.75
$$

1035

735

$2.8 \pm 0.6$

$6.50 \pm 2.00$

212

$23.35 \pm 6.50$

88

$1.5 \pm 0.7$ 
Table 6. The indices, frequency of occurrence $(\% \mathrm{~F})$, percentage of number of each food $(\% \mathrm{~N})$, percentage of wet weight of each food item $(\% \mathrm{~W})$, and percentage relative importance of each food item (\% IRI)

\begin{tabular}{|c|c|c|c|c|c|}
\hline Group & Species & $\% \mathrm{~F}$ & $\% \mathrm{~N}$ & $\% \mathrm{~W}$ & $\%$ IRI \\
\hline FISH & & & 30.83 & 48.18 & 38.29 \\
\hline Bramidae & Brama brama & 4.82 & 0.23 & 2.16 & 0.10 \\
\hline Caesionidae & Dipterygonotus spp & 4.82 & 0.34 & 0.15 & 0.02 \\
\hline Carangidae & $\begin{array}{l}\text { Decapterus russelli } \\
\text { Decapterus spp. }\end{array}$ & 50.60 & 3.12 & 8.07 & 5.04 \\
\hline Clupeidae & $\begin{array}{l}\text { Amblygaster sirm } \\
\text { Amblygaster } \\
\text { clupeoides } \\
\text { Sardinella spp. } \\
\text { Hilsa kelee }\end{array}$ & 61.45 & 3.92 & 11.52 & 8.44 \\
\hline Engraulididae & $\begin{array}{l}\text { Stolephorus spp } \\
\text { Thryssa spp }\end{array}$ & 44.58 & 6.30 & 3.10 & 3.73 \\
\hline Exocoetidae & $\begin{array}{l}\text { Cheilopogon } \\
\text { spilopterus } \\
\text { Cheilopogon spp. } \\
\text { Hirundichthys spp. } \\
\text { Cypselurus spp. }\end{array}$ & 62.65 & 2.95 & 4.00 & 3.88 \\
\hline Ambassidae & Ambassis spp. & 4.82 & 0.68 & 0.14 & 0.04 \\
\hline Sphyraenidae & Sphyraena spp & 53.01 & 8.57 & 13.93 & 10.62 \\
\hline Trichiuridae & $\begin{array}{l}\text { Lepturacanthus spp } \\
\text { Trichiurus spp }\end{array}$ & 73.49 & 4.71 & 5.11 & 6.42 \\
\hline CEPHALOPODS & & & 10.39 & 11.11 & 10.98 \\
\hline Loliginidae & $\begin{array}{l}\text { Loligo spp (small) } \\
\text { Loligo bartrami }\end{array}$ & $\begin{array}{l}62.65 \\
50.60\end{array}$ & $\begin{array}{l}3.07 \\
7.33\end{array}$ & $\begin{array}{l}9.06 \\
2.05\end{array}$ & $\begin{array}{l}6.76 \\
4.22\end{array}$ \\
\hline CRUST ACEANS & & & 58.77 & 40.71 & 50.73 \\
\hline Portunidae & 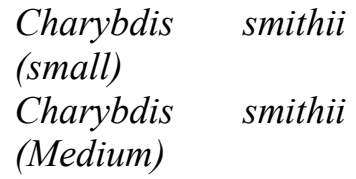 & $\begin{array}{l}77.11 \\
25.30\end{array}$ & $\begin{array}{l}41.74 \\
12.04\end{array}$ & $\begin{array}{l}19.70 \\
20.48\end{array}$ & $\begin{array}{c}42.16 \\
7.32\end{array}$ \\
\hline Peneidae & Penaeus spp. & 25.30 & 5.00 & 0.53 & 1.24 \\
\hline
\end{tabular}

Compared to the study made by Maldeniya (1995), there have been more than two fold increased in fishing effort in the north western coast. As such, increased fishing effort might also be a factor that influenced high yellowfin tuna production in coastal areas of Sri Lanka. However, yellowfin tuna production in 2006 is comparatively higher than in 2005 in both the areas. This increasing production trend may be due to the reasons highlighted by IOTC (2004). 
On the other hand it is reasonable to assume that increased production may be due to the result of variability in the fishing effort in 2005 and 2006 especially in north western coast. The estimated value for $1 n$ (CPUE+1) in 2006 is always greater than 2005 except in August 2006 in north eastern coast. This also highlighted the higher abundance of yellowfin tuna in 2006 compared to 2005. However $\ln (\mathrm{CPUE}+1)$ values have remained more or less same level within a year in the two areas. The estimated CPUE $\left(\mathrm{kg}^{-b o a t} \mathrm{day}^{-1}\right)$ in the North western coat is higher than the values reported by Maldeniya (1995). Though the present study revealed that the fishing season in north western coast was from October to April of the following year, it was reported to be restricted only to two or three months of the year in mid 1990's starting from February (Maldeniya 1995). The expanding of fishing season can be explained by using the economic consideration of fishers, market demand, security situation of the country and changes in oceanic conditions which may affect distribution and abundance of yellowfin tuna. According to Maldeniya (1995), peak production period was reported in March and present study also highlighted the peak production in March 2005 although it shifted to November in 2006. This study indicated that around $97 \%$ of catches consisted of yellowfin tuna in both the areas although it was $80-90 \%$ in the last decade in the north western area (Maldeniya 1995). Either gear design may have influenced the vulnerability of yellowfin tuna or fishers tended to target this species by paying attention to the economic aspects. Use of Carangids and Loliginids as a bait has been reported by Maldeniya (1995) in the north western coast although those baits were not reported in the present study. Present study indicates that the length distribution of yellowfin tuna varied from 40 to $150 \mathrm{~cm}$ fork length (FL). Sivasubramanium (1985) reported that the length of yellowfin tuna targeted by longlines can be within the range of 20 to $145 \mathrm{~cm}$. Maldeniya (1995) has reported much higher length range (71 to $176 \mathrm{~cm}$ ) for yellowfin tuna targeted in the North western area. According to Maldeniya (1995) the highest length frequencies were reported within the range of 130 to $160 \mathrm{~cm}$ in the North western area and the range reported in the present study was 95 to $120 \mathrm{~cm}$. It indicates that comparatively smaller fish were vulnerable to longlines in the North western area compared to the 1993 - 1995 period. Changes of migratory routes or changes in fishing grounds may be possible reasons for this trend. The coastal longline fishery can therefore be considered to be sustained mainly by seasonally migrating yellowfin tuna as suggested by Sivasubramanium (1970, 1971) and Maldeniya and Joseph (1988). Nishida (1992) proposed that there are two major stocks of yellowfin tunas in the Indian Ocean: a western and an eastern stock. According to his study the margin of two stocks are very close to Sri Lankan EEZ and mixing of stocks can occur within this area. As present study reveals more or less same sized fish are caught in both the areas, it might be reasonable to assume that two different stocks are exploited in the two fishing areas. However due to non-availability of information about the migratory patterns of yellowfin tuna, it is difficult to confirm this assumption. The seasonality of the fishery may be due to the environmental 
parameters such as monsoon pattern, availability of food and the water currents (Angel 1994). According to Hanamoto (1987), studies on the distribution of tuna were complicated by the fact that the ocean is threedimensional and also the targeted species may have different vertical preferences. In addition, distribution of food resources may be important and direct factors that control the distribution of yellowfin tuna (Caddy and Rodhouse 1998). As such, shifting of fishing time in the northwestern area may be attributed to either change of vertical migration pattern of yellowfin tuna or availability of their food resources. However, further studies are needed to be carried to explore these relationships.

In the present study, stomach content analyses were performed on individuals caught by coastal tuna longlines which were set at relatively shallow depths compared to offshore longliners. This study reveals that the yellowfin tuna had the most balanced feeding regime of crustaceans, fishes and cephalopods. The result obtained by gut content analysis was compared with those of a previous study. Maldeniya (1996) has identified higher number of fish families (34) compared to the present study. However prey items at the family level and the diversity of the fish prey were comparable to those reported by Maldeniya (1996).

The fish prey was the most important prey by weight for yellowfin tuna and this has also been discussed by Kornilova (1981). However \% IRI of crustaceans was higher than that of fish and cephalopods and this revealed that the pelagic crab $C$. smithii is the most important prey item in the diet of yellowfin tuna. Similar observations have been reported by Potier et al (2007) for large pelagic fish in the Western Indian Ocean. Zamorov et al. (1992) were the first to report the importance ofC. smithii in the diet of yellowfin tuna in the western tropical Indian Ocean. Predation on crabs has also been observed in the eastern tropical Pacific Ocean, where the red crab Pleuroncodes planipes and swimming crabs of the family Portunidae formed the main part of the yellowfin diet in certain areas (Alverson 1963).

Present study also indicated that epipelagic prey items (pelagic crabs and fish) were dominated in the gut contents of yellowfin tuna and this indirectly supports that shallow water inhabitant yellowfin tuna are vulnerable to coastal tuna longline fishery. Further the results indicated that the yellowfin tuna is a piscivorous feeder and the mophometric characteristics such as shorter gut length compared to the body length and high muscular stomach also supported this.

The dietary habit of yellowfin tuna depends on several factors among which smell and the colour of the prey is considered to be the most important (Potier et al. 2007). Tanabe (2001) has discussed that yellowfin tuna is more attracted to silvery and red colored prey items and the high abundance of crabs, squids and fish belongs to family Clupeidae, Engraulididae, Exocoetidae, Sphyraenidae and Trichiuridae can be explained. However colour vision of tuna species especially in the deeper water is still being debated (Fritsches and Warrant 2004). However, the precise information on the composition of prey available in the environment is required to study the 
food electivity in yellowfin tuna. Pelagic swimming crabs, especiallyC. smithii seem to be a possible source of bait for coastal tuna longlining. Further it is recommended to use fish belonging to family Sphyraenidae together with the existing baits such as clupeids and carangids.

\section{Acknowledgements}

The authors would like to thank the National Aquatic Resources Research and Development Agency (NARA) for providing necessary financial support to carry out this study. A note of gratitude is also owed to T.A. Rajapaksha, R.A.M. Jayathilaka, Upul Adikari and T.H. Sunil Shantha for their assistance in the field work and data entering.

\section{References}

Alverson, F.G. 1963.

The food of yellowfin and skipjack tunas in the eastern tropical Pacific Ocean. International Tropical Tuna Commission Bulletin. 7: 293-396

Angel, M.V. 1994.

Spatial distribution of marine organisms: patterns and processes. In: Large-scale Ecology and Conservation Biology, (P.J. Edwards, R.M. May \& N.R. Webb eds.) PP 59-109, Blackwell Scientific Publications, London

Blackburn, M. \& R.M. Laurs 1972.

Distribution of forage of skipjack tuna (Euthynnus pelamis) in the eastern tropical pacific. US Department of Commerce, NOAA Technical Report. NMFS SSRF 649, 16

Caddy,J.F. \& P.G. Rodhouse 1998

Cephalopod and groundfish landings: evidence for ecological change in global fisheries Reviews in Fish Biology and Fisheries 8:431-444.

Collette, B.B. \& C.E. Nauen 1983.

FAO species catalogue. Vol. 2. Scombrids of the world. An annotated and illustrated catalogue of tunas, mackerels, bonitos and related species known to date. FAO Fisheries Synopsis 125:2, 137

Dissanayake, D.C.T. 2006.

Monitoring and assessment of offshore fishery in Sri Lanka. Report submitted for the United Nations University Fisheries Training Programe, Reykjavik, Iceland.

Fishcer, W. \& G. Bianci 1984.

FAO species identification sheets for fishery purposes, Western Indian Ocean, Fishing area 51, vol 1-5: FAO, Rome.

Fritsches, K \& E. W arrant 2004.

Do tuna and billfish see colours? Pelagic Fisheries Research programme, University of Hawai. 9(1): 1- 3

Hanamoto, E. 1987. 
Effect of oceanographic environment on bigeye tuna distribution. Bulletin of the Japanese Society of Fishery Oceanography 51:203216.

IOTC, 2004.

Report of the Sixth Session of the IOTC working party on tropical tunas. Indian Ocean Tuna Commission. Victoria, Seychelles

Joseph, L., C. Amarasiri \& R. Maldeniya 1985.

Driftnet fishery for tuna in the western coastal waters of Sri Lanka. BOBP Working Paper 31:72-84.

Kornilova, G.N. 1981.

Feeding of yellowfin tuna, Thunnus albacares, and bigeye tuna

Thunnus obesus, in the equatorial zone of the Indian Ocean. Journal of Ichthyology. 20, 111-119

Maldeniya, R. 1995.

Small boat tuna longline fishery north-west coast of Sri Lanka. th

Expert Consultation on Indian Ocean Tunas.

Maldeniya, R. 1996.

Food consumption of Yellowfin tuna,Thunnus albacares, in Sri

Lankan waters. Environmental Biology of Fish. 47, 101-107.

Maldeniya, R. \& L. Joseph 1988.

Recruitment and migratory behaviour of yellowfin tuna Thunnus albacares) from the western and southern coasts of Sri Lanka. IndoPacific Tuna Development and Management Programme. IPTP/88/WP/17.

Nishida, T. 1992.

Development of the stock-fishery dynamic model for yellowfin tuna (Thunnus albacares) in the Indian Ocean. Bulletin of Japanese Society of Fisheries Oceanography 56 (3): 263-270.

Nishida, T. \& H. Shono 2006.

Updated stock assessment of tuna resources in the Indian Ocean by age structured production model (ASPM) analyses. Report of the Eighth Session of the IOTC working party on tropical tunas. Victoria, Seychelles

Pinkas, L., M.S. Oliphant \& I.L.K. Iverson 1971.

Food habits of albacore, bluefin tuna and bonito in Californian Waters. Californian Fish Game 152: 1 - 105.

Potier, M., F. Marsac, Y. Chere, V. Lucas, R. Sabatie, O. Maury \& F. Menard 2007.

Forage fauna in the diet of three large pelagic fishes (lancetfish, swordfishand yellowfin tuna) in the western the western equatorial Indian Ocean Fisheries Research 83: 60 - 72.

Samaraweera, V.K. \& C. Amarasiri 2004.

Present status of Billfish fishery in Sri Lanka. $4^{\text {th }}$ Session of the

IOTC Working Party on Billfish, Victoria, Seychelles .

Sivasubramaniam, K. 1970. 
Surface and subsurface fisheries for young and immatureyellowfin tuna (Thunnus albacares) around Sri Lanka. Bulletin of Fisheries Research station, Ceylon 21: 15-25.

Sivasubramaniam, K. 1985.

The tuna fishery in the EEZ $\mathrm{s}$ of India, Maldives and Sri Lanka. BOBP Working Paper 31:19-42. FAO, Rome.

Sivasubramanium, K. 1971.

Apparent abundance of yellowfin and bigeye tuna in the inshore offshore and near oceanic ranges around Ceylon. Bulletin of Fisheries Research station, Ceylon. 21: 58-63.

Tanabe, T. 2001.

Feeding habits of skipjack tuna Katsuwonus pelamis and other tuna Thunnus spp. juveniles in the tropical western Pacific. Fisheries Science 67 (4): $563-570$.

Zamorov, V.V, V.A. Spiridinov \& G.V. Napadovsky 1992.

On the role of the swimming crabCharybdis smithii (Mc Leay 1838) in the feeding habit of yellowfin tuna Thunnus albacares (Bonnaterre).W orkshop on stock assessment of yellowfin tuna in the Indian Ocean, Colombo, Sri Lanka. IPTP Coll. Vol. Work Doc. 6, $70-75$. 